David Blake of the American Association of Medical Colleges says that it could be unethical for the FDA to reject all or part of a clinical trial that was nearly complete. The FDA would be wasting valuable research efforts and money on the one hand, and disregarding the good-faith participation of the patients on the other. Blake favours voluntary disclosure of financial information and adherence to thresholds as outlined in the NIH guidelines. The NIH and NSF rules specify a US $\$ 10,000$ threshold for royalties, payments, and financial holdings before concern over any potential conflict of interest is triggered. Also, with the NIH and NSF proposals the onus will be on researchers and their local institutions, not a centralized federal agency, to decide what constitutes a conflict of interest.

Other groups are considerably less conciliatory towards the FDA. John Siegfried of the Pharmaceutical Research and Manufacturers of America blasts the agency's proposed rules, calling them an "unnecessary and burdensome hindrance to clinical research." Current clinical research practices, particularly doubleblind, randomized control studies, are "sufficient to minimize biases," he says. Siegfried also contends that it would be wasteful, cumbersome, and politically unwise for the FDA to set up a whole new system for obtaining and evaluating personal financial data from US-based clinical investigators and collaborators abroad.

Christine Carrico of the American Association of Pharmaceutical Scientists echoes Siegfried. Members of her organization want the FDA rules modified to be consistent with the NIH and NSF. It is "hard to imagine", she says, that one or a few investigators could bias a properly designed, large-scale multicentre trial.

FDA officials are now pushing industry representatives and academic researchers to admit that some financial conflicts of interest are so egregious that they require tough regulations. And most parties agree that certain practices, particularly linking direct payments or bonuses to favourable clinical trial outcomes, are reprehensible. "We share the view that conflict of interest is a 'state,' not an evil per se", says Robert Temple, deputy director of the FDA Center for Drug Evaluation and Research. But, even though officials are seeking acceptable middle ground to avoid jettisoning the proposed rules, the subtle middle is just where the greatest difficulties seem to lie.

JEFFREY L. FoX Washington, $D C$

\title{
Can Germany still be innovative?
}

Continued resistance from a small, yet influential, minority against new technological developments, such as genetic engineering or novel types of products, has led senior officials of the pharmaceutical company Bayer AG (which has its roots in Germany) to call for a comprehensive discussion on Germany's future as a site for scientific research. The fear is that if domestic political conditions for research and development are not improved, Germany may lose out to countries like the United States and Japan.

This has led Horst Meyer, head of Bayer's Pharmaceuticals Business Group, to ask whether Germany will remain a viable base for its operations in the future. Without referring to any political group by name, Meyer spoke recently to medical journalists at the company's research centre at Wuppertal, Germany.

For Bayer, which besides

Wuppertal, has research

centres in West Haven,

Connecticut, and a recently

opened facility in Kansai

Science City in Japan, this

is a question of utmost im-

portance, Meyer said. In

fact, other companies, like

Hoechst in Frankfurt, are

already considering shifting all, or at least part, of their research and production facilities to other countries in Europe or overseas.

The reasons for the current situation are in large part a deep-rooted mistrust of high-tech developments by some groups that sympathize with the influential Green Party and elements of the Social Democratic Party (SPD). Their strongholds are areas, particularly in Germany's northern and central provinces, where the 'Greens' wield considerable influence in local and state parliaments. In the states of Hessen and North Rhine Westfalia, they are members of a government coalition with the SPD.

It was, for example, resistance from the 'green' environment minister in Hessen that led to the recent shut-down of the Siemens nuclear reprocessing plant in Hanau near Frankfurt am Main and a 10-year delay in the opening of a pilot plant built by the drug company, Hoechst, to produce insulin. Only after several technological 'improvements' had been made upon instruction of the authorities, was Hoechst given permission to use genetic engineering to produce insulin.

But generally speaking, it is also a problem of perception. When talking about the scientific and technological future of Germany (and other countries), most people seem to have computer chips, communication networks and space telescopes on their minds, Meyer

IMAGE
UNAVAILABLE
FOR
COPYRIGHT
REASONS

Genetic engineering is one of Bayer's main research areas. Shown is a test with DNA molecules showing up under ultraviolet light. Inset, Bayer's Horst Meyer.

said. "Nobody thinks of innovative drugs as high-tech products."

As a consequence, Meyer and Pol Bamelis, a member of Bayer's management board, are now pushing for what they call a comprehensive "offensive for progress" (Fortschrittsoffensive). In practice, this means a change of the political winds in Germany - with a possibly increased acceptance of technological innovations and high-tech developments, secure patent time, quick and fair registration procedures and calculable political conditions so that entrepreneurial risk will pay off in the long run. As Bamelis put it, "What we need is an environment that promotes innovation, and that will make high-tech pharmaceutical research in Germany an economically viable proposition in the future as well."

KLAUS DaLlibor Berlin 